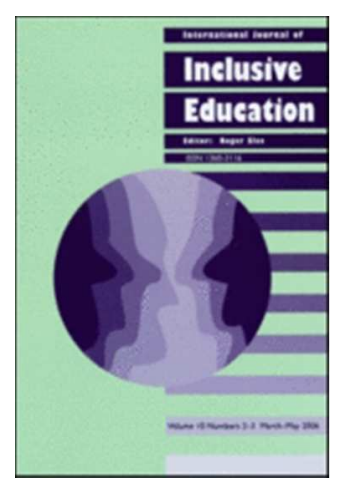

\title{
Inclusion and Social Exclusion Issues in University Education in Prison: Considerations based on the Italian and Spanish Experiences
}

\begin{tabular}{|r|l|}
\hline Journal: & International Journal of Inclusive Education \\
\hline Manuscript ID & Draft \\
\hline Manuscript Type: & Original Article \\
\hline Keywords: & $\begin{array}{l}\text { Prisoners, Higher Education, Social Inclusion, Inclusive Education, Symbolic } \\
\text { Violence }\end{array}$ \\
\hline
\end{tabular}

\section{SCHOLARONE ${ }^{\text {M }}$ \\ Manuscripts}




\title{
Inclusion and Social Exclusion Issues in University Education in
} Prison: Considerations based on the Italian and Spanish Experiences

\begin{abstract}
This paper focuses on university education in prison as a strategic tool for building social inclusion. Using quantitative and qualitative methods, it examines the Italian and Spanish experiences in this area. In Italy and Spain, the idea of punishment having a rehabilitative function has been supported by strong motivation to achieve this ideal. In both countries, the way in which inmates are treated by the prison system was established to oppose prison systems designed by authoritarian regimes. However, the rhetoric of rehabilitation that is now prevalent seems to morally legitimise imprisonment and encourage the emergence of forms of "symbolic violence". For these reasons, focusing attention on higher education in prison takes the form of an analytical and critical exercise that is particularly useful, as it allows the distance between prison and society, and prison and prisoner stereotypes, for example, to be questioned. It also enables the transformative effects that education has on the individual and on the system, beyond any rhetoric of treatment, to be understood.
\end{abstract}

Keywords: Prisoners; Higher Education; Social Inclusion; Inclusive Education; Symbolic Violence

\section{Introduction}

This contribution originates in research work on university education in prison in two southern European countries with very similar prison policy histories: Italy and Spain. In Italy and Spain, the prison system's treatment of inmates, with a re-educational and re-socialising objective, was set up in opposition to the prison systems of fascist dictators Mussolini and Franco. In Italy, the rehabilitative function of punishment is a fundamental principle referred to in Article 27 of the Republican Constitution of 1948. 
In Spain, the treatment system was established after the death of Franco. Article 25 of the Spanish Constitution of 1978, which concerns prison sentences, stresses the importance of the re-education and social rehabilitation of prisoners.

Further developments of these approaches have been promoted by the Council of Europe and the European Union under the definition of minimum standards of detention: consider the preparation of European Prison Rules (2006), adopted by the Council of Europe in 1987 and updated in 2006, and the establishment of the Committee for the Prevention of Torture and Inhuman or Degrading Treatment.

Nevertheless, the European prison system appears contradictory and ambivalent: in theory, it designs and promotes social inclusion; in practice, it continues to ignore the growing distance between prison and society (Maculan, Ronco, and Vianello 2013). The rhetoric of rehabilitation has often morally justified the prison sentence (Ronco 2016). Excessive use of imprisonment has favoured the occurrence of emergency situations in many European prisons (Maculan, Ronco, and Vianello 2013). As noted by many scholars, the U.S. policy of zero tolerance has spread rapidly in Europe (Castel 2004; Garland 2001; Wacquant 2009; Matthews 1999). The problematic advance of globalisation and the economic and financial crisis have led to the redefinition of penal policies from a security perspective ( $\operatorname{Re} 2006)$. What clearly emerges is the establishment of a culture and policy of social control (Garland 2001). Immediate consequences are the redefinition of criminal behaviour and the spread of a dangerous penal populism (Pratt 2007; Hallsworth 2002). Wacquant (2009) refers to a transition from "welfare state" to "penal state". A situation that leads - and which sociodemographic characteristics of the prison population clearly show - to a process of criminalisation of poverty and social insecurity. In the last thirty years in almost all European countries, it has been possible to record an increase in the prison population, 
with a growing proportion of foreigners, drug addicts and socially vulnerable persons (illiterate, unemployed, etc.). There has been no lack of serious emergency situations in both Italy and in Spain, promptly reported by the daily news: overcrowding, suicides, hygiene and health emergencies, etc. On several occasions, the European Court of Human Rights has identified and sanctioned inhuman and degrading treatment related to the structural conditions of the prison system ${ }^{1}$. There have thus been attempts at reform (Ciarpi and Turrini Vita 2015; Tabar et al. 2016), but they have had no structural effects and, above all, have not changed the prevailing culture of punishment and perception of the detainee.

Based on the foregoing, focusing attention on higher education in prison takes the form of a particularly useful analytical and critical exercise, because it permits questioning the distance between prison and society, stereotypes of the prisoner and stereotypes of prison, for example. Furthermore, it permits capturing the transformative effects of education on the individual and on the system, beyond any rhetoric of treatment. The key questions to be asked, then, are: To what extent is university education institutionalised in the two countries in question? What measure are in place to ensure that university education is fully inclusive? To what extent have these measures succeeded, or failed? What purpose do prisoners attribute to university study?

This research will use both quantitative and qualitative data. Besides the use of institutional data for analysis of the Italian context, it will consider the first results of a medium-long term ethnographic research study conducted "undercover" from 2008 to 2016 in the Prison University Campus (PUC) of the Tuscany. This was an experience

\footnotetext{
${ }^{1}$ See i.e. Judgment of 8 January 2013, Torreggiani and Others v. Italy, Appl. nos. 43517/09, $46882 / 09,55400 / 09,57875 / 09,61535 / 09,35315 / 10$ and $37818 / 10$
} 
that allowed direct observation of some prison dynamics, supplemented by informal interviews with prisoners, listening to their life stories, and conversations with educational staff, prison officers and volunteers.

For analysing the specific situation of Spanish prisons, besides the use of institutional data, it will focus on the experience of The National Distance Education University of Madrid (Universidad Nacional de Educación a Distancia - UNED). This university is responsible for the complete provision of higher education in Spanish prisons.

Specifically, it will attempt to understand the process that led Spain to becoming a European excellence in the area of university education in prisons through testimonials obtained during two periods of research at UNED.

\section{Prison and University}

In the collective imagination, prison and university appear as worlds apart, distinct universes: common sense has it that criminals belong to the former and respectable persons to the latter. They are actually further separated by quite a few stereotypes about the prison and inmates. There are negative stereotypes that take the problematic link between crime and punishment for granted and through which the prison population appears to be the main source of social insecurity; "but also positive stereotypes, uncritical regarding the rehabilitative penal ideology and the actual potential of the protections afforded by the regulations on human rights" (Vianello $2012,10)$. In general, the prison is associated with the idea of restriction, the university - ideally considered a place of personal and collective growth, of knowledge and of universal openness - with that of freedom (Pastore 2015). This distance appears even more marked when, having gained access to the place of detention, you find yourself lost in the maze of contradictions that is the prison. It is an extremely opaque place, 
dedicated to protecting one's appearance, "sealing and monitoring the channels through which the daily life of the detained criminals, in its more gory aspects - those that reveal the materiality of social revenge and the rhetoric of rehabilitation - flows, is revealed in the eyes of ordinary citizens" (Oddone and Queirolo Palmas 2014, 139). This can be perceived every time you enter: from the moment you pass through the first gate, from the simple identity control to the always problematic checking of access authorisation, you realise that you are disruptive elements as external individuals and bearers of a relational dimension which, even though contemplated, is never fully accepted and metabolised. Each player in the overall prison system - first the prison officers, then the educational staff - immediately offers, formally and informally, their vision of the situation and corresponding instructions for use. In this way, the entire institution also acts in a strong-handed manner towards others: it imposes rules, limits, discipline and, above all, seeks to win over even the minds most resistent to its still dominant correctionalist ideology (Goffman 1961; Foucault 1975; Combessie 2001; Pavarini 1994; Melossi and Pavarini 1977; Mosconi 1998; Vanina and Vianello 2015).

It is not just a question of the distance between inside and outside, but the more general lack of consistency between what the law requires and what the prison represents. To the visitor's eyes, the prison still appears today primarily as an institute of custody, of mere containment of people. It punishes and protects, controls and condemns. Educational and cultural activities are not exempt from this logic of control founded on the principle of reward. Active participation in cultural and educational initiatives is considered evidence of commitment, of "good behaviour": it is subject to assessment by observation and treatment groups; it contributes to the granting of special permits and other reward measures. 
Instead, study should be a right to be respected, promoted and defended.

Considering study a part of prison treatment appears as a way of implementing new forms of control and "symbolic violence" (Bourdieu 1998). It may therefore be helpful to understand in what way study is enhanced in selected contexts and verify which new elements it introduces into ordinary processes of imprisonment.

\section{The Italian experience and some results}

As noted in the introduction to this paper, everyone - even in situations of incarceration - has the right to study under the provisions of the Italian constitution (Senato della Repubblica 1948) and the articles cited below clearly demonstrate this:

\footnotetext{
All citizens have equal social dignity and are equal before the law, without distinction of sex, race, language, religion, political opinion, personal and social conditions.

It is the duty of the Republic to remove those obstacles of an economic or social nature which constrain the freedom and equality of citizens, thereby impeding the full development of the human person and the effective participation of all workers in the political, economic and social organisation of the country (Art. 3). [...] Punishments may not be inhuman and shall aim at re-educating the convicted (art. 27).

[...] Schools are open to everyone.

[...] Capable and deserving pupils, including those lacking financial resources, have the right to attain the highest levels of education.

The Republic renders this right effective through scholarships, allowances to families and other benefits, which shall be assigned through competitive examinations (art. 34).
}

This framework of values, which already formed the central issue of law no. 354/1975, was fully acknowledged in the Regulation on standards for the prison system and measures involving the deprivation and limitation of liberty (Presidential Decree 230/2000), in which a number of qualitative details may be observed. In article 44, 
paragraph 4 of the Regulation, it states, "prisoners and detainees who are university students are assigned, wherever possible, to sections and rooms suitable for study, and appropriate communal areas are made available". It also states that, "students may be authorised to keep books, publications and other learning aids required for their studies in their own rooms and other study areas". However, the affirmation of the right to university study in prison cannot be limited to a formal, abstract statement; it requires material intervention in order to improve conditions of disparity, and in this respect many prisons have set up so-called Prison University Campuses (PUCs):

a system of services and opportunities offered by a university with the support of the prison administration, which are additional to or substitutes for those normally accessible by students, proposed in a structural way and organised on the basis of specific agreements, aimed at overcoming the obstacles that hampering the effective exercise of the right to university study (Palma et al. 2016, 48).

The following diagram shows in a nutshell the spread of university campuses in different Italian prisons.

(1) Table 1. Prison University Campuses (PUCs) in Italy (1998-2016)

Source: our processing from https://www.giustizia.it/resources/cms/documents/sgep_tavolo9_relazione.pdf (Link verified on June 26, 2017).

\begin{tabular}{|c|c|c|c|c|}
\hline \multicolumn{2}{|c|}{ Denomination } & \multirow{2}{*}{\begin{tabular}{|l|} 
Year \\
1998
\end{tabular}} & \multirow{2}{*}{\begin{tabular}{|l} 
Involved prisons \\
CC of Turin
\end{tabular}} & \multirow{2}{*}{\begin{tabular}{|l} 
Participating Universities \\
University of Turin
\end{tabular}} \\
\hline 1 & PUC of Turin & & & \\
\hline 2 & PUC of Tuscany & $\begin{array}{l}2000 \\
2003 \\
2010\end{array}$ & Prisons in Tuscany & $\begin{array}{l}\text { University of Florence } \\
\text { University of Pisa } \\
\text { University of Siena }\end{array}$ \\
\hline 3 & PUC of Bologna & $\begin{array}{l}2000 \\
2013\end{array}$ & CC di Bologna & University of Bologna \\
\hline 4 & $\begin{array}{l}\text { PUC of Alessandria S. } \\
\text { Michele / Pausania }\end{array}$ & 2001 & $\begin{array}{l}\text { CR (prison for sentence execution) } \\
\text { of Alessandria }\end{array}$ & $\begin{array}{l}\text { University of Piemonte Orientale } \\
\text { A. Avogadro }\end{array}$ \\
\hline
\end{tabular}




\begin{tabular}{|c|c|c|c|c|}
\hline 5 & $\begin{array}{l}\text { University Prison } \\
\text { System of Lazio }\end{array}$ & $\begin{array}{l}2003 \\
2008 \\
2009\end{array}$ & Prisons in Lazio & $\begin{array}{l}\text { University of Tuscia } \\
\text { University of Cassino } \\
\text { "Sapienza" University of Rome, } \\
\text { University of Rome Tor Vergata, } \\
\text { University of Rome "Roma Tre" }\end{array}$ \\
\hline 6 & PUC of Triveneto & 2003 & CR of Padua & University of Padua \\
\hline 7 & $\begin{array}{l}\text { Memorandum of } \\
\text { undertaking DAP } \\
\text { (Department of } \\
\text { Penitentiary } \\
\text { Administration) - } \\
\text { University of Catania } \\
\end{array}$ & 2003 & CC of Caltagirone & University of Catania \\
\hline 8 & PUC of Calabria & 2004 & CC of Catanzaro & $\begin{array}{l}\text { University of Magna Grecia, } \\
\text { Catanzaro }\end{array}$ \\
\hline 9 & PUC of Lecce & 2004 & CC of Lecce & University of Lecce \\
\hline $10 \mid$ & PUC of Sardinia & $\begin{array}{l}2004 \\
2007 \\
2014\end{array}$ & $\begin{array}{l}\text { CC of Sassari / CC of Alghero / } \\
\text { Prisons in Sardinia }\end{array}$ & University of Sassari \\
\hline $11 \mid$ & PUC of Abruzzo & 2005 & Prisons in Abruzzo and Molise & $\begin{array}{l}\text { Leonardo Da Vinci "Telematic" } \\
\text { University of Chieti-Pescara }\end{array}$ \\
\hline $12 \mid$ & PUC of Reggio Emilia & 2005 & CC of Reggio Emilia & $\begin{array}{l}\text { University of Modena e Reggio } \\
\text { Emilia }\end{array}$ \\
\hline 13 & $\begin{array}{l}\text { PUC of Brescia } \\
\text { Verziano } \\
\end{array}$ & 2006 & CR of Brescia Verziano & University of Brescia \\
\hline 14 & PUC of Sulmona & 2006 & CR of Sulmona & University of L'Aquila \\
\hline 15 & $\begin{array}{l}\text { Memorandum of } \\
\text { undertaking DAP - } \\
\text { University of Palermo }\end{array}$ & 2009 & CC Pagliarelli & University of Palermo \\
\hline 16 & $\begin{array}{l}\text { Metropolitan PUC of } \\
\text { Milan }\end{array}$ & 2013 & Prisons in province of Milan & Università of Milan Bicocca \\
\hline 17 & PUC of Teramo & 2014 & CC of Teramo & University of Teramo \\
\hline 18 & PUC of Ferrara & 2014 & CC of Ferrara & University of Ferrara \\
\hline
\end{tabular}

The incidence of PUCs shows that they are distributed in penal institutions across the whole of Italy, but it is also apparent that from a quantitative perspective they are actually quite few in number, particularly when you consider the number of penal institutions (190), inmates, universities and the potential to fully implement the agreements. The various experiences are also extremely diverse in terms of organisational structure and the education on offer. There are many genuine exceptions within an overall context of general suppression, experiences that whilst officially set up by the institution, only survive due to the goodwill and strong motivation of lecturers, tutors, educators and volunteers. 
Quantitative results relating to the numbers of prisoners enrolled on degree programmes are clearly also testimony to the scant regard the institutions have for academic study. According to the latest surveys up to 31 December 2015, the total number of detainees enrolled at universities was 178 , a figure that represents a decline ${ }^{2}$ compared with earlier surveys, as evidenced in the graph below:

Figure 1. University students in prison in Italy (2008-2015)

Source: our elaboration on data provided by Ministero della Giustizia, www.giustizia.it

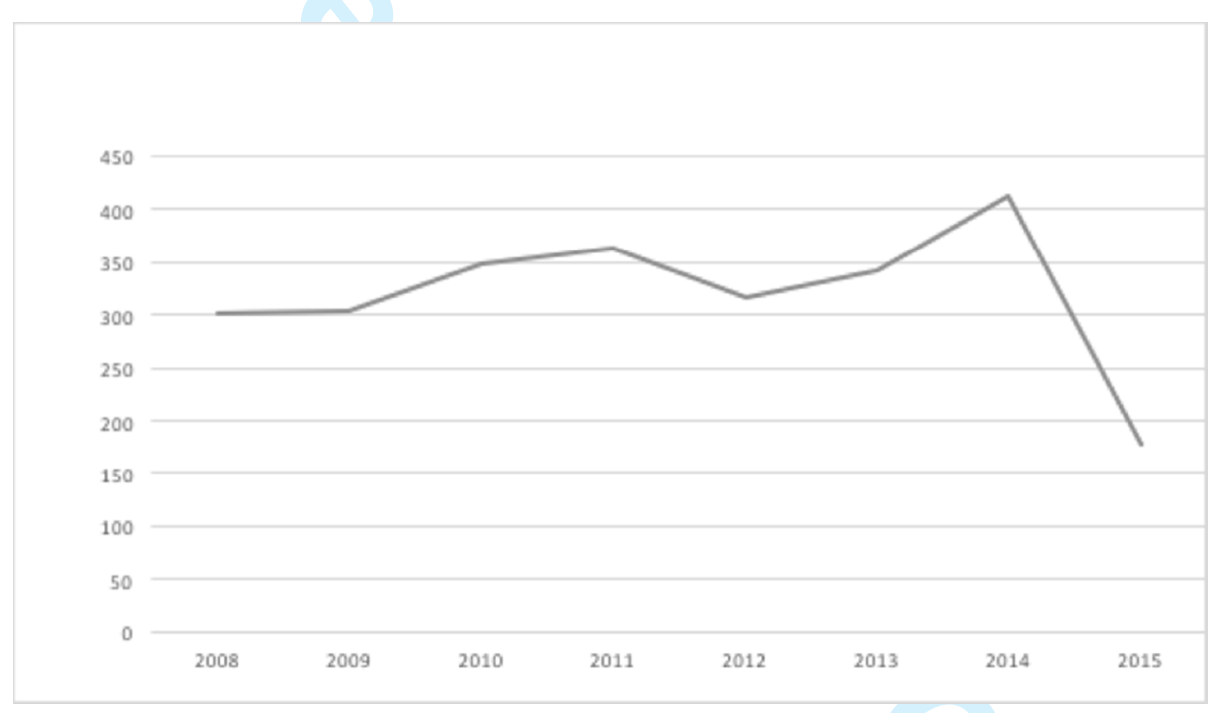

Despite everything, in the daily and always problematic attempt to limit the coercive nature of a total institution, Prison University Campuses in the Italian context

\footnotetext{
${ }^{2}$ It is true that the number of detainees also dropped during the period in question, but it is likewise true that the number of detainees in possession of the relevant university entry qualifications was higher. The drop in the number of enrolments cannot therefore be attributed to the reduction in prison population.
} 
pursue important educational goals and aspire to be seen as ideal bridges between prison and society (Migliori 2004; 2007; Pastore 2015).

A close critical look at the problematic elements is perhaps a good place to start in order to remedy this dangerous lack of inclusivity. In this respect it may be useful to examine the Spanish experience to identify good practice in providing more democratic and inclusive academic education in prisons.

\section{The Spanish experience and some results}

At the end of the Franco's rule as dictator in Spain, reform of the penitentiary system was immediately given central importance in the process of democratisation. Just one year after the Spanish constitution came into effect in 1979, the "Ley Orgánica Penitenziaria" was approved, which emphasised the importance of reforming prisons and measures for custodial detention in accordance with constitutional provisions.

With reference to the specific focus of this work, note that the process of institutionalising university study in prison was the result of an agreement signed in 1983 between UNED, the Ministry of Education, the Ministry of Justice and the Prison Authority. The policy applied in this period by the Socialists, involving the cultural transformation of prisons, resulted in an extremely rapid increase of university students among the prison population (Viedma Rojas 2013). Further consolidation of UNED's role in prisons came in 2003 when the Aznar government brought in legislation ${ }^{3}$ requiring state universities to enter into agreements with prison authorities when providing services to prisoners, and adapt their teaching methods to the prison

\footnotetext{
${ }^{3}$ This legislative intervention was linked to the need to put an end to a series of administrative irregularities and favouritism involving UPV. For an accurate representation of the specific legislative issue, see Viedma Rojas's comprehensive work of 2013.
} 
environment; a condition that only UNED was able to guarantee, and in fact, since 2003 UNED has been the only university operating in Spanish prisons. The results obtained in terms of developing educational programmes, social inclusion and innovation are particularly valuable. Between 2003 and 2009, the number of prisoners enrolled on university courses increased significantly, as shown in Figure $2^{4}$.

Figure 2. University students in prison in Spain (2008-2015)

Source: our elaboration on data provided by Oficina de Calidad de la Uned and Viedma (2013)

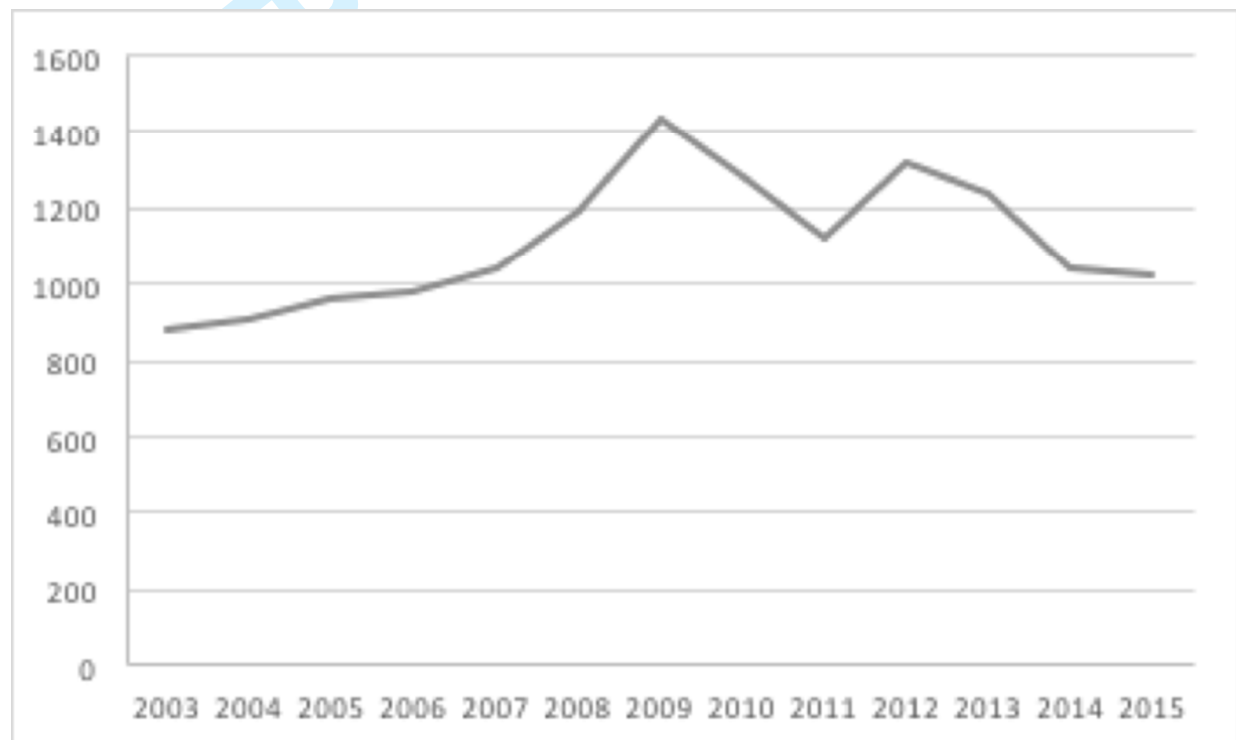

Although many prisoners lack the immediate preparation necessary to pass university admission examinations, UNED's commitment has been to be to help the access to university education of this group through an orientation and induction course. The course, with particular support from all the Associated Centers of the UNED,

\footnotetext{
${ }^{4}$ The recorded decline between 2010 and 2015 may be partially due to the decline in the prison population. The average number of detainees in Spanish prisons in 2010 was 76,108, which fell to 64,563 in 2015 .
} 
intends to to provide interested persons basic university entrance training and a detailed introduction to university studies centred on UNED's specific methodology.

\section{Exploring differences between Italian and Spanish experiences}

The prison population in Italy and Spain is very similar in terms of both numbers and socio-demographic situation. Spain has 119 recently constructed prisons which are generally larger than Italian prisons. Although the incarceration rate is higher in Spain than in Italy, a permanent feature of the Italian prison system appears to be the cyclical emergency of overcrowding. In addition, another anomaly found in Italian prisons is the high percentage of prisoners on remand (pre-trial detainees), accounting for $34 \%$ of the total prison population. In Spain, on the other hand, the percentage of pre-trial detainees is much lower, in line with that of Germany and the United Kingdom. There are also obvious similarities with reference to the legislative framework, as mentioned above.

But shifting the focus to the main subject of this paper - university education in prison - it is possible to perceive particularly significant organizational, quantitative and qualitative differences.

As noted, the difference between Italy and Spain regarding the participation of prisoners in university courses is evident (fig. 3).

Figure 3. University students in prison in Spain and Italy (2008-2015)

Source: our processing from https://www.giustizia.it/giustizia/it/mg_1_14.wp (for Italy) and Secretaría General del Instituciones Penitenciarias http://www.institucionpenitenciaria.es (for Spain). 


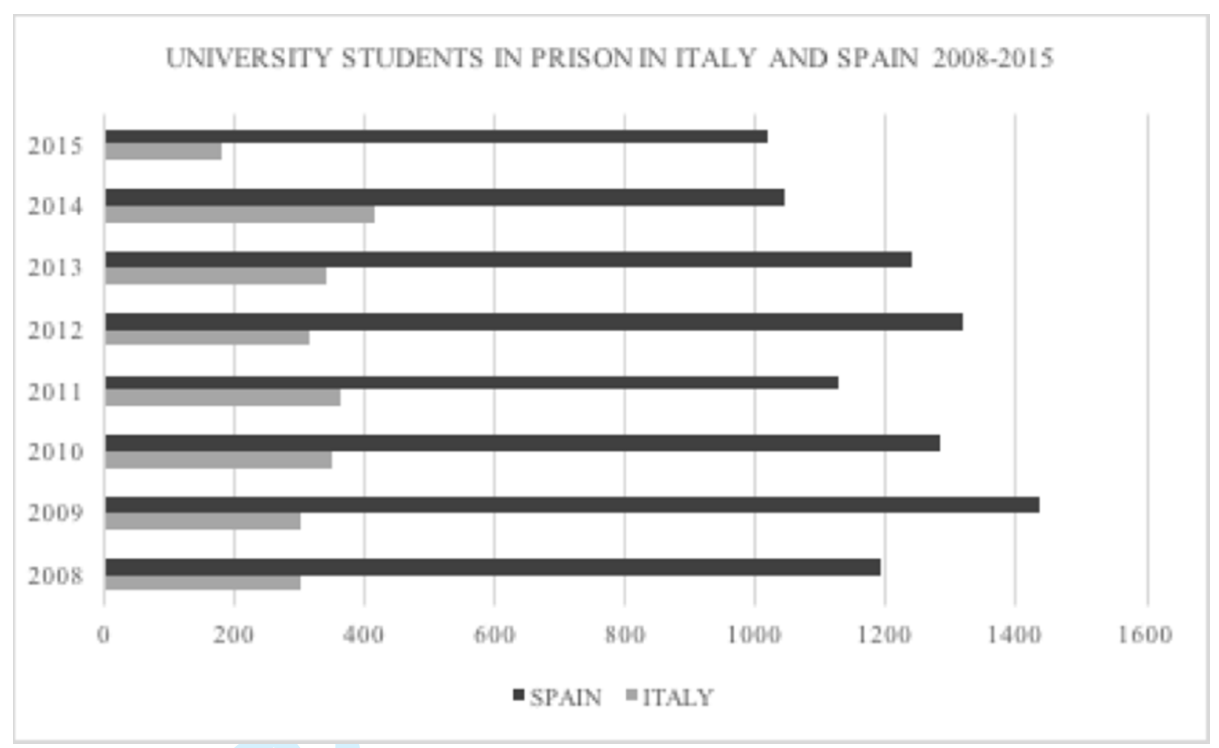

This difference calls for the most general organisational and institutional differences relating to university education in prison to be considered in both contexts.

As Pillera observed in 2016, by dynamically adapting to the changes practised by prisons and society, the two models of university education in Italian and Spanish prisons have, in some measure, responded to the principal demands that have emerged in European regulations (equality between education and work, integration with the state system, specific resources and support materials), although with the accent on different, probably complementary, aspects. Spain has done notable work at continental level, at least as regards the range of users and the length of their experience.

The strong point of the Spanish experience is undoubtedly the employment of innovative teaching methods designed for distance learning through the apposite use of ICT (Gutiérrez Brito, Viedma Rojas, and Callejo Gallego 2010; Viedma Rojas 2013). But the truly distinctive element is the organisational model that provides a comprehensive offer of university education that is evenly distributed across the country. The events leading to the start-up and consolidation of UNED's digital campus in Spanish prisons are competently explained by Prof. Antonio Viedma Rojas of UNED 
of Madrid. Firstly, the close collaboration between UNED technicians and those at the penitentiary institutions. Essentially, access to digital learning spaces for university students in Spanish prisons comprises the following features:

- Communication and navigation are secure and controlled at all times.

- Information traffic from the prison centre to the UNED facility and vice versa is constantly monitored.

- The technology used ensures that students can only access educational services.

In practice, students have free access to the digital platform for teaching materials, exercises and exam schedules, but they cannot send materials via this connection.

- Communication between students and tutors is via direct meetings supported by UNED staff.

The diagram below shows the overall structure of the UNED system.

Figure 4. General structure of the digital system for university education in Spanish prisons

Source: Adapted by Viedma Rojas (2017)

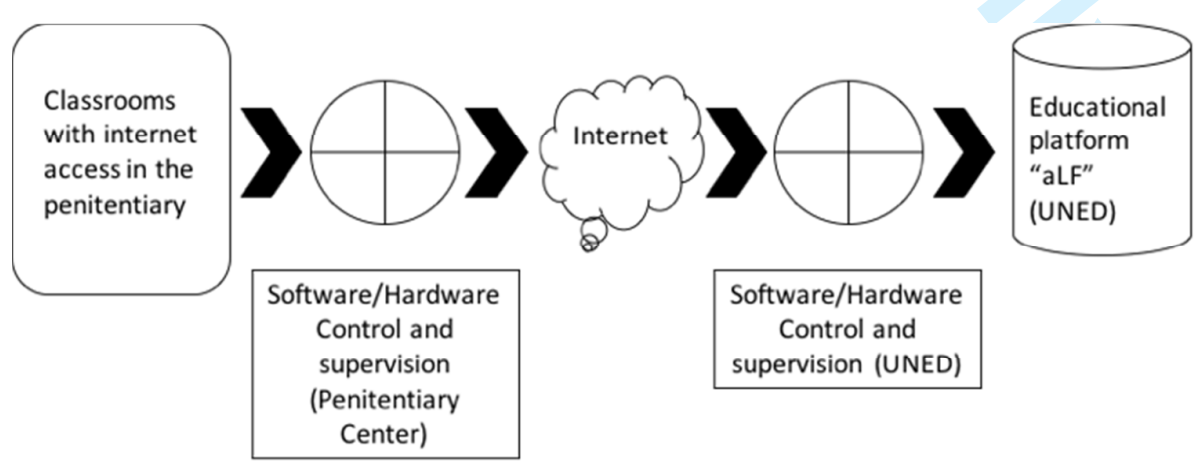


Clearly, such a system would never have seen the light of day without the strong institutional motivation that provided the financial and human resources to support the whole process.

In the Italian context, however, the Prison University Campuses make up for the limitations of a disparate distribution across the country and scant financial support from the institutions. In addition to these limitations there is also a lack of parity in educational provision and services, and an overall delay in the roll-out of ICT provision. Experimental forms of e-learning designed specifically for university education have so far been introduced in very few institutions, and have had no impact on the system (Diana 2013; Arcangeli et al. 2010). What is urgently needed is rationalisation of the existing provision and introduction of an integrated and non-discriminatory national system of Prison University Campuses. To this end, the Spanish experience can be considered a potential model and could doubtless indicate good practice to be used in the Italian context.

Regarding the significance and importance of university study in prison, it may be useful to be guided by the testimonies of those who are currently undergoing this experience. The following paragraph will then look beyond the statistics to understand the transformative power of study and reiterate the necessity for truly inclusive educational provision.

\section{Elements for reflection on the significance of university study in prison ${ }^{5}$}

University study is often presented as the exception within the overall processes of cultural impoverishment and subjective destruction typical of the prison system.

\footnotetext{
${ }^{5}$ This paragraph will consider the first results of a medium-long term ethnographic research study conducted "undercover" from 2008 to 2016 in the Prison University Campus (PUC) of the Tuscany.
} 
Unfortunately though, it is often the case that no appropriate procedures are set up alongside the agreed acts and protocols, either internally or externally, to support and encourage the experience. Priorities seem to lie elsewhere it seems, and culture can wait until the time is right, often indefinitely. This is the perception when visiting prisons, and especially listening to the stories that prisoners relate of their own experiences of detention and education. As told by Renato ${ }^{6}$, a PUC student in Tuscany:

[...] when I transferred to the centre it wasn't the ideal situation because you never find an ideal situation in prison [...] Well, you can't really think of there being a section where it's all university students and only university students are in there. You're still in prison, the needs of the prison and the section always come first. So what does that mean? It means that if the prison is overcrowded, you can't be alone in your cell to study if you've got exams. You're forced to be with another three, four or five people. For example, when I came here it was in a period of intense overcrowding and there were three of us in a tiny cell, not all of us university students. If I wanted to study in the evening it was a problem because my cellmate wanted to watch TV or something. It's a bit better now, but it's still chaos (Renato, Tuscany PUC).

The thing that strikes you most when you go into a prison is the perennial chaos that reigns everywhere, even in the spaces that are supposed to be set aside for study. There's a continuous hubbub; the deafening noise of armoured doors being constantly slammed, the rattling of keys and the periodic battering ${ }^{7}$. Then there are the voices

\footnotetext{
${ }^{6}$ The names of prisoners interviewed have been all changed, in order to guarantee the anonymity of the interviewees.

${ }^{7}$ The term "battering" within a penitentiary refers to the way the prison officers check the state of the iron grilles and barred windows, a process that is carried out several times in a day (usually at the start of a new shift) and consists of "battering" all the metallic components of windows with a bar to check they are sound.
} 
yelling out prisoners' names to hand out orders and pass on information: "therapy", "choir", "school", "assistant", "mail", etc.

The invitation to seriously consider the possibilities offered by the encounter between prison and university comes from inmates themselves. Despite the many difficulties, both objective and subjective, structural and contingent, they make a daily declaration of resistance in order to give a new meaning to their life path. Clearly, inmates also use study in an instrumental fashion in order to obtain better conditions and be judged positively: special permits, access to special sections, general improvement of prison conditions, etc. After all, this is the logic of treatment rewarding. However, careful reading of the life stories of those who decide to study in prison reveals much more important meanings and values.

For an inmate, the university path is primarily a way of resisting the devastating effect of the slow passage of time; a way of countering monotony, that steady stream of days that are always the same.

\begin{abstract}
I started studying, driven more than anything else by the desire not to throw time away. I didn't have a strong motivation to obtain a degree [...] I think that in most cases the guys who decide to enrol in university do so primarily to keep themselves busy, then in some cases the pleasure of studying and the desire to improve take over. And if you manage to improve in here, in large part you improve despite the prison and not thanks to the prison (Antonio, Tuscany PUC).
\end{abstract}

I think I would have gone mad without studying [...] I am an active person, I have always worked. Keeping a prisoner inside without giving him other instruments, all you have is a caged beast that gets angrier [...] I'm afraid of depression, that my brain will stop, and this is also why I study: so that there is "food" for the mind (Aldo, Tuscany PUC).

When Luca, another of the prisoner interviewed, recalls his university studies in a Tuscan prison, he talks about his exams as goals that allowed him to give meaning to his days, to hope, to 'see other things': 
each exam gives you more strength and time flies. Whenever I took an exam two months had gone by, my day was full, I had no time for anything else. And then it was a way to stay anchored to the outside world ... seeing professors, studying, staying up to date on what was happening outside (Luca, Tuscany PUC).

Studying places the individual-inmate in a new dimension, offering alternative perspectives and the implications in terms of social status are of special value, as an extract from a letter-testimony by a PUC student in Padua clearly shows:

\begin{abstract}
One day, something happened that particularly struck me. I asked a volunteer to help me fill out my CV. Reaching the item on profession, I wanted to write detainee - after all I don't have a job in here - but she stopped me, saying that, as well as being detained, I was also a student, so I should write this.

It might seem like a banal conversation, but her words warmed my heart because that's when I realised that she was not speaking to me as a detainee, but that she considered me above all a person, and first of all a person who was studying. Of course I don't forget why I'm in here, but I'm glad that people see something in me besides the offence, and if this is success, it's thanks to the magic of studying. Maybe I'm exaggerating by using the word magic, but there's something wonderful in being seen as a normal person, even if only in the eyes of those who appreciate my efforts to build myself a new life, made of study and respect for others ${ }^{8}$.
\end{abstract}

Choosing a university path is, therefore, a way of extricating yourself from an indistinct mass, for making yourself recognisable and reaffirming your presence in the world. In this way, study emerges as a relationship: with oneself, with the teacher, with institutions and with society. Through study, moments of freedom are experienced in advance of the terms of imprisonment. Freedom of thought begins to recover people and return them to society in their new capacity as students.

\footnotetext{
${ }^{8}$ The reference is to a letter by Gentian Germani, In prison you can study for changing, published in the "Letters from prison" section of Il Mattino di Padova, 2 November 2009.
} 
However, the transformation is not without its problems and intense internal conflicts.

\begin{abstract}
You change for the better, without a shadow of a doubt, but it's a change that inevitably throws you into crisis, because it calls into question everything you've been your whole life [...] In some ways, you're no longer the person you were before, but you're not someone else yet ... when you have to face the world again wearing "new clothes" that are not yours yet, you're not comfortable in them, but your old clothes don't suit you any more either, so you have to gamble on new things. But it's hard to do it on your own; it's essential you get help from institutions. But from to my own experience so far, I can say that studying doesn't have the same status as work, for example. You don't get probation for study, whereas you do for work; you don't get out on day release for study, whereas you do for work. This [...] is hugely limiting and it means the justice system doesn't believe in study [...] And even the tutors - who represent the university - it's not like they're viewed positively by the system [...] The university that comes into prison has to act almost like a guest, there's no real collaboration [...] Even to bring teaching materials in, they have to go through check upon check and questioning (Giuseppe, PUP of Tuscany).
\end{abstract}

So, as Antonio suggested in one of the passages above, in order to improve you have to advance "in spite of the prison". It is therefore essential to gamble on possible alternative links so as not to lose motivation, to avoid the risk of giving up on the path you've started out on and fall back into the 'existence with no life' to which a detainee's lot too often reverts. In order to stem these potential deviations, the university too must stand firm in order for life and renewal to take place, through the relationships that underpin the teaching and the projects that are introduced in the prison. To establish healthy relationships of trust, possible meetings, debates and cooperation. As Massimo, another university student that we interviewed, puts it:

Over the years I've spent studying, I've been preparing to get out without a gap between inside and outside. I've tried to keep in touch with my tutors, I talk to them when I'm on parole. This has enabled me to maintain a thread between the illogical nature of prison and the logic of the outside. I've always had to fight to make sure 
the thread doesn't get broken. Naturally, there have been times when I've felt despondent, but I've had support (always from the outside) and I've overcome it. For us [detainees] little things are important, we magnify everything and give importance to the smallest of details. This conversation is nice because it's a break with the monotony and gives me contact with the outside, maintains my link with what's happening on the outside, so much the better if helps to raise awareness.

Enhancing these meanings is perhaps the best way to free themselves from that gallows culture (Pavarini 2011) which continues to be the real distinguishing feature of the prison and gamble, beyond all the rhetoric, on rehabilitation and re-socialisation of the offender for the start of a genuine process of social integration.

\section{Concluding remarks}

In the light of what has been said so far, the extraordinary nature of the convergence of prison and university can be viewed from a number of different aspects, both specific and general. In terms of specifics, study appears to be one of the most effective ways of attenuating the disastrous nature of incarceration and giving it a constructive element that can raise prisoners above themselves, so to speak, and also raise the institution and those running it, at every level. Any initial awkwardness, or even favouritism, can be overcome by increasing uptake amongst penal institutions. This can be achieved inasmuch as study activity enables the growth of teaching and dissemination of ethics that in the medium term constitute the basis for the long-awaited success of the constitution. Study, then, is not just the act of studying; it's about introducing broader values that are more significant, and if possible the Utopian content that is particularly effective, both for individuals and for the institutions in which they are held, made up of its various legislative and executive components. In this sense, study is acknowledged as having the potential to promote improvement of the system. 
Considering the more general aspects on the other hand, the value of university education in prisons must also be viewed on a symbolic level. Encouraging prisoners to participate in university programmes reminds everyone that a different culture of punishment is possible without the "do-gooder" attitude, the concessions and the subterfuge, by honing the nature of prisons and the manner in which detention operates. Steering policy interventions in this direction could generate positive effects for the system and greatly advance the resultant need for change, indicating collective repossession of the processes of education and shared acceptance of responsibility by the whole community, schools and universities.

Acknowledgements

\section{References}

Arcangeli, B., P. Diana, F. di Mieri, and G. Suriano. 2010. 'L'e-Learning in carcere: una Proposta." Journal of E-Learning and Knowledge Society 6 (1): 91-99.

Bourdieu, P. 1998. Practical Reason: On the Theory of Action. Standford, CA: Stanford University Press.

Castel, R. 2004. L'insicurezza sociale. Che significa essere protetti. Torino: Einaudi.

Ciarpi, M., and R. Turrini Vita. 2015. Le trasformazioni del probation in Europa. Roma: Laurus Robuffo.

Combessie, P. 2001. Sociologie de La Prison. Parigi: La Découverte.

Council of Europe. 2006. "European Prison Rules. Recommendation Rec(2006)2 of the Committee of Ministers to Member States on the European Prison Rules." Strasbourg Cedex, France.

Diana, P. 2013. “L'E-Learning in Carcere: esperienze, riflessioni e proposte.” Cambio, 
no. 6: 261-71. doi:10.1400/218601.

Foucault, M. 1975. Discipline and Punish: The Birth of the Prison. New York: Random House.

Garland, D. 2001. The Culture of Control : Crime and Social Order in Contemporary Society. Chicago: University of Chicago Press.

Goffman, E. 1961. Asylums: Essays on the Social Situation of Mental Patients. New York: Anchor Books.

Gutiérrez Brito, J., A. Viedma Rojas, and M. J. Callejo Gallego. 2010. “Estudios Superiores en la Educación Penitenciaria Española: Un Análisis Empírico a Partir de Los Actores.” Revista de Educación, no. 353.

Hallsworth, S. 2002. "The Case for a Postmodern Penality.” Theoretical Criminology VI, 2: 145-64.

Maculan, A., D. Ronco, and F. Vianello. 2013. Prison in Europe: Overview and Trends. Roma: Antigone Edizioni.

http://www.prisonobservatory.org/upload/PrisoninEuropeOverviewandtrends.pdf.

Matthews, R. 1999. Doing Time: An Introduction to the Sociology of Imprisonment. London: Macmillan Press LTD.

Melossi, D., and M. Pavarini. 1977. Carcere e fabbrica. Alle origini del sistema penitenziario. Bologna: il Mulino.

Migliori, S. 2004. Lo studio e la pena. L'università di Firenze nel carcere di Prato: Rapporto Triennale 2000-2003. Firenze: Firenze University Press.

- 2007. Conoscere il carcere. Storia, tendenze, esperienze locali e strategie formative. Roma: Carocci.

Mosconi, G. 1998. Dentro il carcere, oltre la pena. Padova: Cedam.

Oddone, C., and L. Queirolo Palmas. 2014. "Loro Fuori. Per una ricerca Sociale PostCarceraria.” In Loro Dentro. Giovani, Migranti, Detenuti, edited by R. Beneduce, L. Queirolo Palmas, and C. Oddone. Genova: Professional Dreamers.

Palma, M., D. Albertini, F. Cavalli, S. Ferraro, C. Marzagalli, D. Mosso, S. Rossi, M. Tolu, A. Vallini, and V. Venturini. 2016. “Stati Generali dell'esecuzione penale. Tavolo 9 - Istruzione, Cultura, Sport.” Roma. 
https://www.giustizia.it/resources/cms/documents/sgep_tavolo9_relazione.pdf.

Pastore, G. 2015. "Formazione e processi di inclusione sociale: il caso dei Poli Universitari Penitenziari." In XENIA. Nuove sfide per l'integrazione sociale, edited by M. A. Toscano and A. Cirillo. Milano: FrancoAngeli.

Pavarini, M. 1994. I nuovi confini della penalità. Introduzione alla sociologia della pena. Bologna: Edizioni Martina.

—_. 2011. "La polizia, la sua riforma, la società aperta.” In Nuove Strategie di polizia per una "società aperta," edited by U. Curi and G. Palombari. Padova: Cedam.

Pratt, J. 2007. Penal Populism. London: Routledge.

Re, L. 2006. Carcere e globalizzazione. Roma-Bari: Laterza.

Ronco, D. 2016. “La competizione tra i reclusi. L'impatto della scarsità di risorse sulla comunità carceraria.” Etnografia e Ricerca Qualitativa, no. 2: 211-26. doi:10.3240/84118.

Senato della Repubblica. 1948. "Constitution of the Italian Republic.” Roma.

Tabar, O. F., M. Miravalle, D. Ronco, and G. Torrente. 2016. Reducing the Prison Population in Europe: Do Community Based Sentences Work? Roma: Antigone Edizioni. http://www.prisonobservatory.org/upload/EPO_2_WS1_Final_report.pdf.

Vanina, F., and F. Vianello. 2015. "La ricerca in carcere in Argentina e in Italia. Strategie del penitenziario e pratiche di resistenza." Etnografia e Ricerca Qualitativa, 321-42. doi:10.3240/80821 LA - it.

Vianello, F. 2012. Il carcere. Sociologia del penitenziario. Roma: Carocci.

Viedma Rojas, A. 2013. “Universitarios En Prisión: Experiencias Y Apariencias de Sentido En El Espacio Penitenciario.” Universidad Nacional de Educación a Distancia - UNED, Madrid.

—. 2017. "La Situación de La Educación En Prisión En España: Realidades Y Expectativas de Transformacón.”, forthcoming.

Wacquant, L. J. D. 2009. Punishing the Poor: The Neoliberal Government of Social Insecurity. Durham, NC: Duke University Press. 
